\title{
Emergence of 'Candidatus Liberibacter solanacearum'-Infected Seed Potato in Relation to the Time of Infection
}

Arash Rashed, University of Idaho, Aberdeen R\&E Center, Aberdeen 83210, and Texas A\&M AgriLife Research and Extension Center, Amarillo 79109; and Fekede Workneh, Li Paetzold, and Charles M. Rush, Texas A\&M AgriLife Research and Extension Center, Amarillo

\begin{abstract}
Rashed, A., Workneh, F., Paetzold, L., and Rush, C. M. 2015. Emergence of 'Candidatus Liberibacter solanacearum'-infected seed potato in relation to the time of infection. Plant Dis. 99:274-280.

Zebra chip (ZC) is a disease of potato, putatively caused by the vectorborne bacterium 'Candidatus Liberibacter solanacearum'. Although $\mathrm{ZC}$ has been a major concern due its significant negative impact on both potato yield and quality, its effect on seed potato sprouting has been the subject of recent evaluations. The present study was conducted to determine whether variation in emergence is affected by the infection duration of ' $\mathrm{Ca}$. L. solanacearum'-infected seed potato prior to harvest. Furthermore, changes in pathogen detectability and titer levels in late-season-infected plants also were evaluated during and after cold storage. The rate of $\mathrm{ZC}$-affected seed potato emergence following cold storage was not affected by the time of infection in the field, and the majority of ZC-infected tubers failed to sprout. Time to "seedling" emergence also was significantly longer in seed potato from plants infected $\geq 2$ weeks before harvest. The small percentage of plants that emerged from ZC-affected seed potato produced stunted,

nonvigorous plants that often died after a few weeks. The rate of successful ' $\mathrm{Ca}$. L. solanacearum' detection increased during cold storage, suggesting a continued ' $\mathrm{Ca}$. L. solanacearum'-tuber interaction postharvest. After tubers were removed from cold storage and held at room temperature, ' $\mathrm{Ca}$. L. solanacearum' titer started to increase. Although none of the tubers from plants infected 1 week before harvest exhibited any disease symptoms or tested positive for ' $\mathrm{Ca}$. L. solanacearum' at harvest, up to $38 \%$ of these tubers tested positive following placement at room temperature after cold storage. Results of this study suggest that the role of seedborne $\mathrm{ZC}$ in disease epidemiology is likely to be insignificant. Furthermore, the findings of this study emphasized the importance of continued control measures until at least a week before harvest, and highlighted the need for improved methods of ' $\mathrm{Ca}$. L. solanacearum' detection at harvest, especially in tubers infected late in the season.
\end{abstract}

Successful seed germination requires the presence of adequate physiological traits that support seedling establishment in its dynamic field environment (29). Plant pathogens are one of the biotic variables that can influence viability of planted seed and impact subsequent plant generations, if the pathogen can be transmitted from seed to emerging plants (15).

In the United States, the vast majority of commercial potato fields are planted with "seed potato", from vegetative propagation, instead of true potato seed. As with other vegetatively propagated crops, health of the parent plant is paramount, and infection of the parent by a systemic pathogen can result in infection and reduced quality in the next generation $(5,23,25)$. If the pathogen is vectorborne, then infected plants may serve as a source of primary inoculum and as infection foci, if the vector is present.

Zebra chip (ZC) is a disease in potato (Solanum tuberosum L.), associated with the phloem-limited bacterium 'Candidatus Liberibacter solanacearum'. The pathogen is transmitted by the tomato and potato psyllid Bactericera cockerelli Sulc (Hemiptera: Triozidae) (8). ZC was initially discovered in northeastern Mexico in 1994. Subsequently, it was reported from Texas in 2000 (14) and, since then, it has been found in several other potato-growing states, most recently in Idaho, Oregon, and Washington (3,7). After inoculation by the psyllid vector, ' $C a$. L. solanacearum' is systemically distributed throughout the infected host plant (11). In addition to potato, ' $\mathrm{Ca}$. L. solanacearum' may infect several other commercially important solanaceous plants such as tomato, eggplant, and pepper.

Corresponding author: A. Rashed, E-mail: arashed@uidaho.edu

Accepted for publication 28 August 2014.

http://dx.doi.org/10.1094/PDIS-04-14-0421-RE

(c) 2015 The American Phytopathological Society
The onset of ZC foliar symptoms occurs 3 to 4 weeks following infection (disease incubation period) and is initially characterized by curling of the leaves and chlorosis (22). A significant yield reduction is expected when infections occur early in the season (22), especially during the tuber initiation stage of potato plant development (4). In addition, production quality can be affected by ' $\mathrm{Ca}$. L. solanacearum' infections, even those that occur as late as 2 weeks before harvest $(21,22)$. Reduced quality is due to the typical ZC symptoms in infected tubers, which are characterized by brown discoloration of vascular and medullar rays. Tuber symptoms may start to appear as early as 2 weeks following infection (22). The severity of ZC symptoms in tuber tissue is correlated with duration of infection and is associated with shifts in the levels of phenolics, reducing sugars, and some amino acids (21). Browning of the freshly cut potato has been attributed to elevated phenolic levels in the presence of polyphenol oxidases (30). When exposed to high temperatures, elevated levels of some amino acids in combination with increased reducing sugar concentrations may produce a brown-colored product known as acrylamide (26); this Maillarddriven production of undesirable color (and flavor) has resulted in loads of potato being rejected by processing companies.

Soon after ZC was first reported in the United States, questions arose as to the potential for the disease to be spread to new production areas by infected seed potato. Initially, the common belief was that ZC-affected potato tubers would rarely emerge (24). Henne et al. (9) showed that the percent emergence of symptomatic tubers was reported to be between 20 and $40 \%$; this observed range in emergence was attributed to differences in plant cultivar and symptom severity in the seed tuber. Plants which emerged from ' $\mathrm{C} a$. L. solanacearum'-infected tubers typically remained small and weak and usually died within weeks (9). However, a considerably higher rate $(93.6 \%)$ of emergence from ' $\mathrm{Ca}$. L. solanacearum'-infected tubers was reported from New Zealand (18). Pitman and colleagues (18) also reported that $70 \%$ of asymptomatic plants produced from infected seed potato tested positive for the pathogen, 
renewing concern about the epidemiological significance of seedborne ZC.

If symptom severity, as proposed by Henne et al. (9), is associated with the emergence rate, then the length of time that the potato is infected during the season (i.e., from time of initial infection until harvest) may help explain reported differences in emergence. This is because symptom severity is highly correlated with duration of ' $C a$. L. solanacearum' infection (22). To date, studies on emergence of ' $\mathrm{Ca}$. L. solanacearum'-infected tubers have been based on field-collected tubers without any knowledge of the time they were initially infested with bacteriliferous psyllids. Investigating the potential relationship between duration of infection and probability of emergence of ' $C a$. L. solanacearum'-infected tubers could provide key information to assist producers in developing more precise ZC management plans. The present study was set to address this shortfall by planting stored seed potato collected from plants which had been infected for durations ranging from 1 to 9 weeks before harvest. These plants initially were used in an independent study to quantify the relationships among time of infection, pathogen quantity, and symptom progress (22).

As a biologically active structure, the potato tuber is expected to maintain interaction with its environment following harvest (10). Such interactions have the potential to impact tuber physiology and quality over time. In addition, initial findings from this study led to the speculation that ' $\mathrm{Ca}$. L. solanacearum' may continue to interact with host tissue postharvest and during storage. Thus, changes in the frequency of ' $\mathrm{Ca}$. L. solanacearum' detection and titer during and after cold storage were evaluated as the second objective of this study. Findings are discussed in the context of ZC epidemiology, and suggestions are made to improve certification of ' $\mathrm{Ca}$. L. solanacearum'-free seed potato.

\section{Materials and Methods}

Sources of infected seed tubers. The study was conducted at the Texas A\&M AgriLife Research and Extension Center, Bushland. Seed potato of 'FL1867' were planted in the field in April 2011 and covered with mesh cages (100 by 100 by $100 \mathrm{~cm})$ prior to emergence. Sunguard II fiberglass rods (Geotek Inc., Stewartville, MN) and fine netting (750 mesh; US Global Resources, Seattle) were used to assemble these tent-shaped cages. For presentation clarity, these relatively small cages are referred to as tent cages. Potato plants emerged in May, approximately 1 month after planting. Following emergence, plants were thinned, such that one plant was located at each corner of the tent cage, approximately 50 to $60 \mathrm{~cm}$ apart (four plants per cage). The field was fertilized with ammonium sulfate (21-0-0-5; Wilbur-Ellis, Hereford, TX) at the rate of $180 \mathrm{~kg} / \mathrm{ha}(150 \mathrm{lb} / \mathrm{acre})$ prior to planting, and irrigated with $6.35 \mathrm{~cm}$ (2.5 in.) of water weekly (center-pivot irrigation). Potato psyllids from ' $\mathrm{Ca}$. L. solanacearum'-positive colonies were used to infest the tent cages (20).

Bacteriliferous psyllid colonies were maintained in the greenhouse for several generations. Psyllids were reared on potato plants (FL1867) in bugdorm mesh and plastic cages ( 60 by 60 by $60-\mathrm{cm}$; BioQuip Products, Rancho Dominguez, CA). Potato plants were replaced with fresh healthy hosts as needed. For the first two infestations, 10 randomly selected psyllids from each colony were tested individually. Random samples of potato psyllids were tested to confirm the ' $\mathrm{Ca}$. L. solanacearum'-positive status of the greenhouse colonies prior to each of the remaining infestations. Evaluated samples never tested negative for the pathogen. Based on results from an independent study, the frequency of ' $\mathrm{Ca}$. L. solanacearum'-positive psyllids in our colony was known to be approximately 97\% (20). Psyllids were of the Central haplotype (28) and ' $\mathrm{Ca}$. L. solanacearum' was a mixed population of A and B haplotypes (32).

Infestations with the psyllids were started on 21 May, approximately 10 days post emergence, and continued every week until a week before harvest on 22 July 2011, for a total of nine infestations (or "infestation treatments"). There were 4 cage replicates per infestation treatment (a total of 36 cages, plus 4 noninfested con- trol tent cages), arranged in a randomized complete block design. Each tent cage was infested by releasing 30 potato psyllids from the ' $\mathrm{Ca}$. L. solanacearum'-positive colonies at the base of the plant positioned at the front left corner of each of the tent cages. Hereafter, we refer to this plant position as plant 1 . Plant 2 was positioned on the same row next to plant 1 (back left corner); plants 3 (back right corner of the cage) and 4 (front right corner of the cage) were located on the next row. Insects were allowed to feed on plants for 1 week. Although multiple insects are expected to inoculate plants within hours (1), a 1-week inoculation access period allowed time for the psyllids to disperse onto the three remaining plants in each of the cages. When the 1-week period elapsed, plants were sprayed with a tank mixture of Movento at $15.5 \mathrm{ml} / \mathrm{liter}$ (Bayer CropScience, Durham, NC), Agri-Mek at $23.4 \mathrm{ml} / \mathrm{liter}$, and Fulfill at $0.79 \mathrm{~g} /$ liter (Syngenta Crop Protection, LLC, Greensboro, NC). The mix was reapplied a week later to assure removal of the infective psyllids. At harvest, potato tubers from plant 1 in each tent cage were sampled for pathogen quantification. Tubers obtained from the rest of the plants in each cage were sampled prior to planting the following year to verify their infection status. After sampling, collected tissues were stored at $-80^{\circ} \mathrm{C}$, until DNA extractions were performed. The total number of harvested potato tubers was 4 to 17 tubers/plant. After visual scoring for ZC symptom severity (all four plants per cage) and collecting tissue samples for ' $\mathrm{Ca}$. L. solanacearum' quantification (only plant 1 ), tubers were moved into cold storage, where they were kept at $4.5^{\circ} \mathrm{C}$ with an average relative humidity (RH) of $96.7 \%$.

Plant emergence from ZC-affected seed potato. After 9 to 10 months of cold storage, tubers were removed and placed at 26 to $28^{\circ} \mathrm{C}$ for 4 days before field planting. All tubers were planted as a whole piece (uncut). The field plant emergence study consisted of three large experimental cages. Hereafter, we refer to these cages as emergence cage 1 through 3 . The first emergence cage was planted on 4 April and contained 253 tubers collected from plants on which the psyllids were initially released (plant 1 ). These plants were the first to develop foliar ZC symptoms in 2011 but it should be noted that infestations conducted $<3$ weeks before harvest did not develop foliar symptoms. The second emergence cage was planted on 9 May and contained 293 tubers collected from the second plant in each of the 2011 tent cages that developed foliar symptoms of ZC. Because plants in cages infected 1 to 2 weeks before harvest did not develop foliar symptoms, tubers from plant 2 were used to seed the second emergence cage. The third emergence cage was planted on 17 May and was seeded with 168 tubers collected from plants 3 and 4 of 2011 infestations conducted 1 and 2 weeks before harvest. The third emergence cage only included tubers collected from the infestations conducted 1 and 2 weeks before harvest, because earlier observations of the first two emergence cages indicated a somewhat higher rate of emergence for late-infected tubers.

In each emergence cage, seed potato were planted in four rows, approximately $40 \mathrm{~cm}$ apart, and covered with two long mesh cloths (described above) stretched over multiple fiberglass poles. Thus, emergence cage dimensions varied based on the number of tubers planted (approximately 17 to 30 by $1.8-\mathrm{m}$ ). Each emergence cage was scouted at 3-day intervals for up to 2 months. Emergence status (emerged or not emerged) was recorded for each tuber. At the end of each experiment, plants that emerged were tested for ' $\mathrm{Ca}$. $\mathrm{L}$. solanacearum' by removing a 100 - to $150-\mathrm{mg}$ sample from the stem tissue just above the soil level; in foliar tissue of potato, ' $\mathrm{Ca}$. L. solanacearum' detection is known to be the highest in the stem tissue (33).

Storage study. Tubers of FL1867 potato were planted in April 2012. Planted tubers were covered before emergence using tent cages (100 by 100 by $100 \mathrm{~cm}$ ), as previously described. After emergence, plants were thinned such that there were only four plants in each cage. There were eight tent cages. Plants in four of these cages were infected (infested with the bacteriliferous psyllids) 2 weeks before harvest and plants in the remaining four cages were infected 1 week before harvest. Unlike the previous study, 
here, every plant in each tent cage was infested by releasing seven infective potato psyllids at the base of the main stem to assure homogeneity of infection among plants. Plants were exposed to the infective potato psyllids for 1 week. At harvest, all tubers were collected and sampled at the stolon attachment end, using a Harris Uni-core sampler 6 (Ted Pella Inc., Redding, CA) for ' $\mathrm{Ca}$. L. solanacearum' quantification (described below). Tissue samples were stored at $-80^{\circ} \mathrm{C}$ until DNA extraction. All tubers were moved into cold-room storage $\left(5.5^{\circ} \mathrm{C}, 94.3\right.$ to $\left.100.4 \% \mathrm{RH}\right)$ immediately after sampling.

Tubers were subjected to three different storage durations, hereafter referred to as "cold-storage sets". The first cold-storage set was removed from the cold room after 2 months and placed at room temperature $\left(22\right.$ to $\left.24^{\circ} \mathrm{C}\right)$. The second and third cold-storage sets were moved into room temperature after 4 and 6 months, respectively. Each of the cold-storage sets consisted of two randomly selected tubers from every plant infected 1 and 2 weeks before harvest. Therefore, each cold-storage set included 32 tubers harvested 1 week before harvest, 32 tubers harvested 2 weeks before harvest, and an additional 8 control tubers from noninfected plants as negative controls. Tubers were sampled immediately following weeks while being maintained at ambient room temperature. Thus, there were a total of seven samplings for every tuber, one at harvest and six following cold storage. To quantify changes in ' $C a$. L. solanacearum' titer over time, tuber tissue samples (approximately $100 \mathrm{mg}$ ) were removed from the immediate proximities around the stolon attachment point, which was previously sampled at harvest. All samples were kept at $-80^{\circ} \mathrm{C}$ until DNA extraction.

Following the last sampling conducted 5 weeks after cold storage, all tubers were planted in 1-gal. pots filled with sand and Sun-
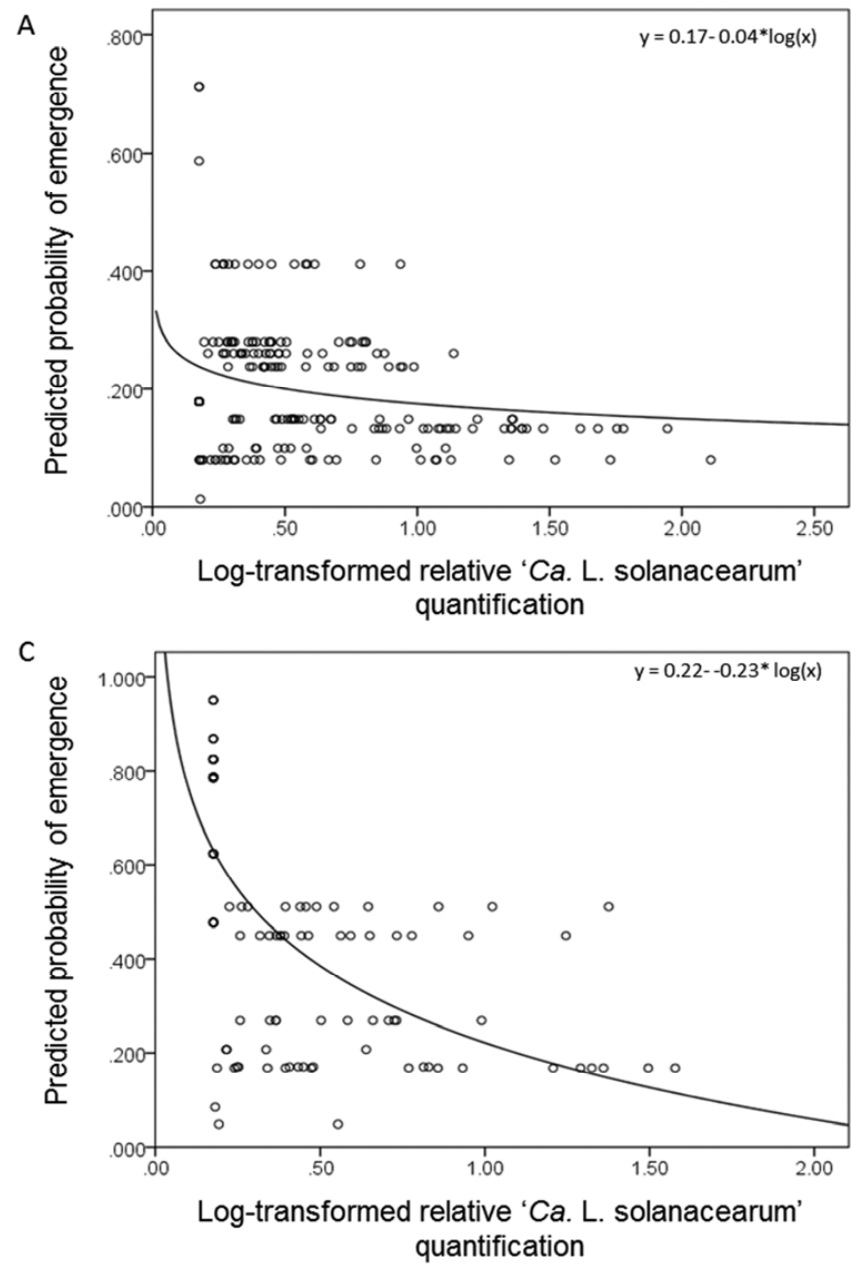
cold storage and, after that, on a weekly basis for five consecutive

grow potting mix (Carrollton, TX). Plant emergence was recorded 6 weeks after planting. Any seeded pot which did not have a seedling after 6 weeks was kept for another 4 weeks to confirm emergence failure. Emerged plants were all sampled at the base of the aboveground stem and evaluated for ' $\mathrm{Ca}$. L. solanacearum'.

DNA extraction and ' $\boldsymbol{C a}$. L. solanacearum' quantification. A modified DNeasy Plant Mini Kit (Qiagen, Valencia, CA) protocol was used to extract DNA from the potato tubers. Immediately after removing samples from $-80^{\circ} \mathrm{C}$ storage, finely chopped tuber samples (approximately $100 \mathrm{mg}$ ) were placed in liquid nitrogen for 120 $\mathrm{s}$ and ground in a Hard Tissue Grinder (VWR, Sugar Land, TX), using a 5-mm stainless-steel ball bearing bead. Final DNA product was eluted in $100 \mu$ l of the elusion buffer.

Using an Applied Biosystems (Carlsbad, CA) 7500 real-time polymerase chain reaction (PCR) system, a comparative cycle threshold $(\mathrm{Ct})$ method $(\Delta \Delta \mathrm{Ct})$ was applied to quantify ' $\mathrm{Ca}$. L. solanacearum' within plant tissue. The reaction mix consisted of TaqMan Universal Master Mix (Applied Biosystems), $0.3 \mu \mathrm{M}$ forward primer LsoF (12), $0.3 \mu \mathrm{M}$ reverse primer $\operatorname{HLBr}(13)$, and $0.25 \mu \mathrm{M}$ HLBp TaqMan probe (13). Eukaryotic 18S ribosomal RNA (VIC/MGB probe, primer limited; Applied Biosystems) was the endogenous control. The amount of target in each sample was normalized to the ' $\mathrm{Ca}$. L. solanacearum' endogenous reference and quantified in relation to the calibrator containing 50,000 genome copies (relative quantification [RQ]).

Statistical analyses. Binary logistic regressions were used to evaluate the effects of infestation treatment and plant replicate on emergence in each of the three experimental cages. Subsequent Pearson correlations were used to examine overall relationship between ' $C a$. L. solanacearum' quantity from all the infestations and predicted probability of successful emergence generated by the

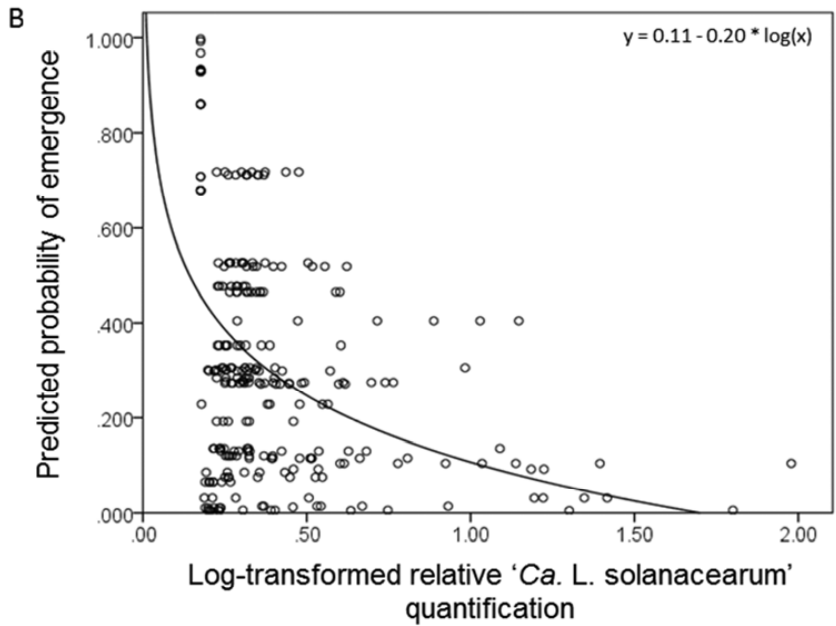

Fig. 1. Relationship between predicted probability of emergence and titer in 'Candidatus Liberibacter solanacearum' affected seed potato in emergence cages A, 1; B, 2; and C, 3. 
binary logistic regression model. Each emergence cage was analyzed separately due to differences in patterns of disease appearance among the four plants within the 2011 infestation cages, as previously described (20).

To compare the number of days to plant emergence among tubers from different infestations (including noninfected controls), analysis of variance was used. Plant replicate and infestation were treated as the categorical factors. For the cold-storage study, a repeated mixed-effects model was used to evaluate changes in ' $\mathrm{Ca}$. L. solanacearum', both during cold storage and after the tuber placement in room temperature. Plant replicate, infestation treatment, cold-storage set, and infestation-storage set interaction were treated as categorical variables in the initial model. Plant replicate and infestation-storage set interaction were removed in a stepwise approach only where their effect was nonsignificant. Binary logistic regression was used to compare effects of storage duration and infestation treatment on emergence. Pearson correlation evaluated the relationship between predicted probability of emergence and titer in the tissue samples collected 5 weeks after storage (before planting). Regardless of the infection status, all tubers collected from infested plants were included in this analysis.

\section{Results}

Plant emergence from $\mathrm{ZC}$-affected seed potato. Overall, variation in the probability of successful plant emergence was not statistically significant among infestation treatments (cage 1: Wald $\chi^{2}{ }_{8}=8.82, P=0.358$; cage 2 : Wald $\chi_{8}^{2}=10.46, P=0.243$; cage 3 : Wald $\left.\chi_{1}^{2}=1.98, P=0.159\right)$. Plants on which the bacteriliferous psyllids were released (plant 1) were the first to exhibit foliar symptoms within each cage. For those plants, average emergence of the infected tubers (pooled across infestation treatments) was estimated at $20.8 \%$. The average rate of emergence of tubers collected from the second plant that developed foliar symptoms within each tent cage was determined to be at $26.5 \%$. An average emergence rate of $50.7 \%$ was reported from the emergence cage 3, which only included plants infected 1 and 2 weeks before harvest. However, $33 \%$ of those seedlings (cage 3 ) emerged from the tubers that tested negative for ' $\mathrm{Ca}$. L. solanacearum' prior to planting. Noninfected control seed potato had $100 \%$ emergence. With the exception of cage 2 (Wald $\chi_{3}^{2}=18.8, P<0.001$ ), emergence was not influenced by plant replicate $(P>0.160)$. Predicted probabilities of emergence were significantly negatively affected by ' $\mathrm{Ca}$. L. solanacearum' titer in all three emergence cages (logarithmic regression, $P<0.002$; Fig. $1 \mathrm{~A}-\mathrm{C})$.

Tubers from plants on which infective psyllids were initially released (emergence cage 1) showed variation in emergence date among different infestation treatments $\left(F_{8,66}=99.94, P<0.001\right.$; Fig. 2A). Noninfected control tubers and tubers from plants infected 1 week before harvest had the shortest emergence time, because they uniformly emerged between 14 and 17 days after planting (Fig. 2A). The effect of plant replicate was largely nonsignificant and this variable was excluded from the final model $\left(F_{3,63}\right.$ $=1.68, P=0.180)$. In emergence cage 2 , seed potato from plants which were infected 1 week before harvest (mean number of days \pm standard error $=14.92 \pm 1.2)$ and the noninfected controls $(16.78$ \pm 4.6) emerged significantly faster than tubers from plants which were infected 3 weeks before harvest or earlier $\left(F_{8,98}=17.60, P<\right.$ 0.001; Fig. 2B). Although seed potato from plants infected 2 weeks before harvest emerged later than those infected 1 week before harvest and the noninfected controls, statistically (Tukey's honestly significant difference), they formed a homogenous subset, different from both earlier $(P=0.066)$ and later $(P=0.120)$ infestations (Fig. 2B). There was no significant effect of plant replicate $\left(F_{3,98}=\right.$ $2.60, P=0.060)$. In emergence cage 3 , tubers from noninfested plants $(13.97 \pm 0.20)$ and tubers from plants which were infected 1 week before harvest $(13.57 \pm 0.17)$ emerged significantly faster than the tubers from plants infected 2 weeks before harvest $(22.26$ $\pm 2.0)\left(F_{2,80}=28.43, P<0.001\right.$; Fig. $\left.2 \mathrm{C}\right)$. The effect of plant replicate was largely nonsignificant $\left(F_{3,77}=1.88, P=0.140\right)$ and this variable was excluded from final model.
The number of days it took for plants to emerge was not affected by the pathogen quantity in two of the experimental cages (Pearson correlations, cage $1: r=0.191, P=0.220, N=88$; cage $2: r=$ $0.210, P=0.052, N=43$ ). In the experimental cage 3 , however, there was a significant positive association between time to emergence and titer $(\mathrm{r}=0.47, \mathrm{P}<0.001, N=54)$.

Storage study. A repeated-measure mixed-effect model revealed a significant change in titer levels of tubers from plants infected either 1 or 2 weeks before harvest, during cold storage $\left(F_{1,191}=\right.$ 16.54, $P<0.001)$. The observed effect was consistent across all three storage duration sets $\left(F_{2,186}=0.33, P=0.721\right)$, and coldstorage set factor was removed from the final model. Change in 'Ca. L. solanacearum' titer was significantly different between tubers collected from the two infestation treatments; there was a greater change in titer levels of tubers infected 2 weeks before harvest compared with the ones infected 1 week before harvest $F_{1,186}=5.04, P=0.021$ ).

When placed at room temperature after cold storage, the percentage of tubers that tested positive for ' $\mathrm{Ca}$. L. solanacearum' increased over time (Fig. 3A-C). This increase was statistically significant in tubers from plants infected 1 week before harvest, a pattern consistent across all the three cold-storage sets $(P<0.003$; Fig. 3A-C). Although the percentage of successful ' $\mathrm{Ca}$. L. solanacearum' detection also increased in tubers from plants which were infected 2 weeks before harvest (Fig. 3A-C), this relationship was statistically nonsignificant for tubers which were kept in cold storage for longer than 4 months (Fig. 3B and C).

Pathogen titer was significantly different among the three storage durations $\left(F_{2,98.01}=11.84, P<0.001\right.$; Fig. 4A-C $)$. Post hoc
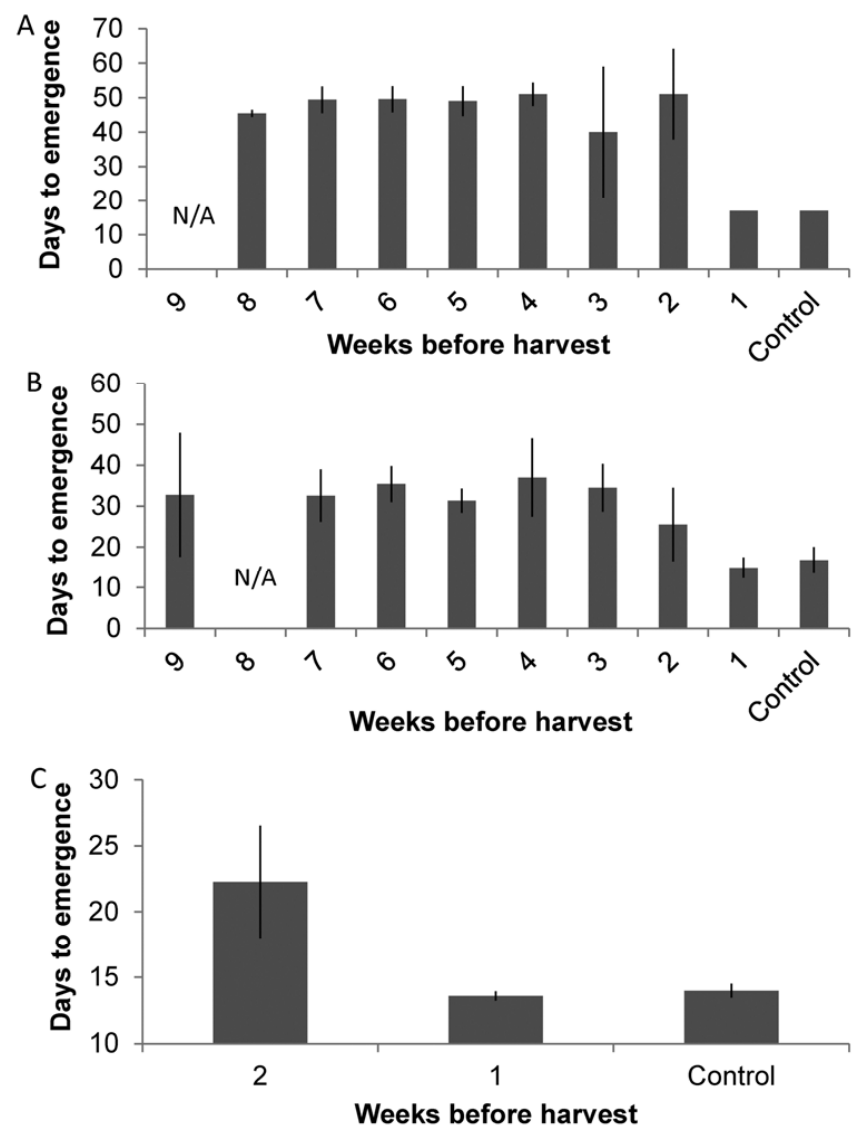

Fig. 2. Number of days it took for plants to emerge from tubers from different infestation treatments. A, Results from the first emergence cage containing tubers from plants on which psyllids were originally released within inoculation cages. B, Results from the second experimental cage, which contained tubers collected from the second plant that exhibited zebra chip symptoms within the previous years' inoculation cages. C, Time to plant emergence in tubers from the two remaining plants in inoculation cages from infestations conducted 1 and 2 weeks before harvest. Error bars represent $95 \%$ confidence intervals. 
pairwise least significant difference comparisons revealed that the observed variation was primarily due to significantly lower titer levels in tubers from storage duration of 2 months (mean RQ \pm standard error $=78.9 \pm 13.3$ ) than those which had been stored for 6 months $(418.0 \pm 135.1)(P<0.001)$. ' $C a$. L. solanacearum' titer showed a significant increase over time following the placement of tubers at room temperature $\left(F_{5,102}=29.22, P<0.001\right.$; Fig. $\left.4 \mathrm{~A}-\mathrm{C}\right)$, a consistent pattern detected in tubers of both infestation treatments (plants infested 1 or 2 weeks before harvest), as revealed by a nonsignificant treatment-sampling period interaction $\left(F_{5,102}=2.00, P=0.084\right.$; Fig. $\left.4 \mathrm{~A}-\mathrm{C}\right)$. Overall, tubers from plants infected 2 weeks $(301.6 \pm 65.6)$ before harvest had a significantly higher ' $\mathrm{Ca}$. L. solanacearum' titer than tubers from plants which were infested, with potato psyllids, a week $(120.5 \pm 30.3)$ before harvest $\left(F_{1,98.73}=11.71, P=0.001\right)$.

The frequency of ' $\mathrm{Ca}$. L. solanacearum' detection failure in potato tubers declined over time when the tubers were transferred into room temperature. In plants infected 1 week before harvest, the highest percentage of tubers that tested positive for ' $\mathrm{Ca}$. L. solanacearum' was between 25 and $38 \%$ at 4 to 5 weeks after placement at room temperature (Fig. 5A). In plants which were infected 2 weeks before harvest, the highest percentage of ' $C a$. L. solanacearum'-positive tubers was 66 to $69 \%$. In this treatment, the highest percentage of positive tubers was detected between 3 and 4 weeks after placement at room temperature (Fig. 5B). Immediately following cold storage, ' $\mathrm{Ca}$. L. solanacearum' was undetectable in tubers from plants which were infected 1 week before harvest, indicating that changes in ' $\mathrm{Ca}$. L. solanacearum' titer became more pronounced after tuber placement at 22 to $24^{\circ} \mathrm{C}$.

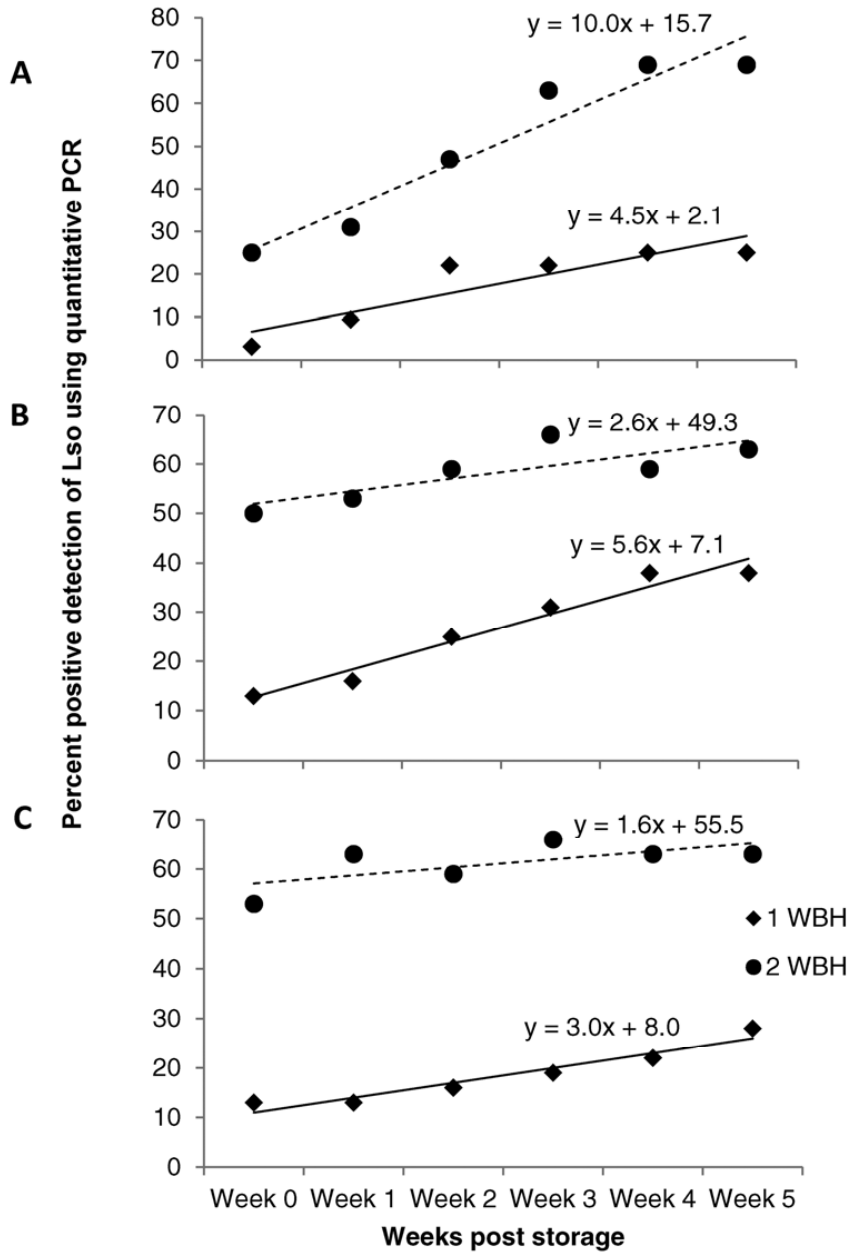

Fig. 3. Changes in percentage of tubers that tested positive for 'Candidatus Liberibacter solanacearum' over time, during 5 weeks of placement at room temperature, after A, 2; B, 4; and C, 6 months of cold storage.
Unlike the field emergence study, probability of successful plant emergence was significantly higher in tubers from plants which were infected 1 week before harvest than from those infected 2 weeks before harvest (Wald $\chi_{1}^{2}=17.16, P<0.001$ ). Duration of storage, however, had no impact on emergence of the seed potato (Wald $\chi_{2}^{2}=$ $3.04, P<0.218)$. Predicted probability of emergence was significantly negatively associated with titer $(r=-0.144, P<0.001)$.

In total, 192 tubers collected from plants which were infected either 1 or 2 weeks before harvest were planted after cold storage, following 5 weeks of placement at room temperature. Of these planted tubers, 105 failed to emerge (54.7\%), only 4 of which tested negative for ' $\mathrm{Ca}$. L. solanacearum' prior to planting. Overall, $67.7 \%$ of the tubers from plants infected 1 week before harvest emerged. Only 5 of the 65 emerged plants $(7.69 \%)$ originated from ' $\mathrm{Ca}$. L. solanacearum'-positive seed potato, of which 3 tested positive for the pathogen $(4.6 \%)$. Emergence in four of those seedlings originated from ' $\mathrm{Ca}$. L. solanacearum'-positive tubers and occurred 3 to 4 weeks later than emergence of the ' $\mathrm{Ca}$. L. solanacearum'-negative tubers. This result is in agreement with results from the field emergence study. Percent successful emergence was $41.6 \%$ for the tubers harvested from plants, which were infected 2 weeks before harvest; only 6 of the 40 (15\%) emerged seedlings were from ' $\mathrm{Ca}$. L. solanacearum'-positive tubers, of which only 1 tested positive for ' $C a$. L. solanacearum' (2.5\%). In this treatment, delayed emergence of 3 to 4 weeks was observed in five of the seedlings, which initiated from ' $C a$. L. solanacearum'-positive tubers.

\section{Discussion}

The majority of ' $C a$. L. solanacearum'-infected seed potato did not emerge, a result in agreement with Henne et al. (9). The small

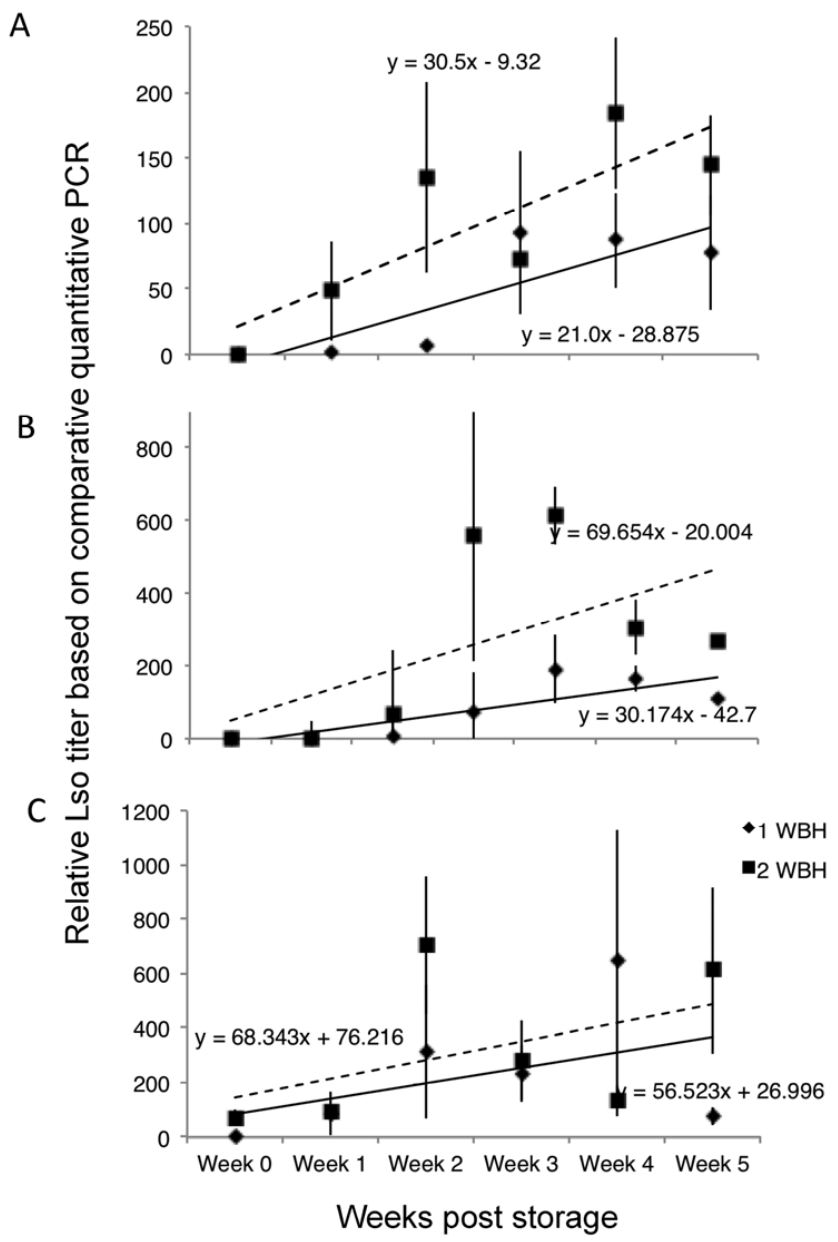

Fig. 4. Changes in 'Candidatus Liberibacter solanacearum' titer over time, during 5 weeks of placement at room temperature, after A, 2; B, 4; and C, 6 months of cold storage. Error bars represent $95 \%$ confidence intervals. 
percentage of the infected tubers that sprouted emerged significantly later than the noninfected controls. The predicted probability of successful emergence was negatively correlated with ' $\mathrm{Ca}$. L. solanacearum' titer.

Evaluations of plant emergence from ZC-affected seed potato were conducted in three different cages, based on the order of foliar symptom appearance of the host plant during the field season. Disease symptoms of the plant on which the psyllids were originally released (plant 1) appeared at least a week earlier than other plants within the cage (22). For this reason, data analyses of the emergence cages were conducted separately. This nonrandom pattern of symptom appearance within each of the tent cages was perhaps because of the potato psyllid tendency to remain on the plant they originally infested (22), a behavior that could also explain the gradual weekly increase in symptomatic plants in commercial fields $(9,34)$.

Results indicated that even tubers from plants which were infested with the bacteriliferous psyllids 1 week before harvest had a significantly reduced emergence when compared with noninfected controls. Although these tubers were asymptomatic and tested negative for ' $\mathrm{Ca}$. L. solanacearum' at harvest, the pathogen was likely present at undetectable levels yet sufficient to induce changes in tuber biochemistry. Indeed, it has been shown that shifts in tuber biochemistry start soon after pathogen translocation in seed potato (21). Such physiological alternations in response to ' $\mathrm{Ca}$. L. solanacearum' may explain the low emergence of tubers from infected plants. However, the observed negative relationship between titer and emergence remains to be investigated in more detail. We showed previously that titer levels in the ZC-affected tubers may decrease following several weeks of infection, even though disease symptoms continued to progress (22), a phenomenon which has been attributed to continuous and cumulative plant defense response (31). A previous field study showed that tubers of different infection durations vary in the degree of $\mathrm{ZC}$ symptom severity (22). The fact that the rate of emergence of tubers infected at different weeks before harvest formed a statistically homogenous subset, which was significantly lower than that of noninfected controls, and indicated that emergence is likely to be independent from the time of infection (or "duration of infection") in the field. Although, statistically, no differences were detected among emergence rates of tubers infected over time during the field season, tubers infected 1 week before harvest showed a relatively higher rate of emergence than tubers infected 2 weeks before harvest across all three field emergence cages. Although this consistent trend suggested the existence of an effect, more replicated studies focused on late-season infestations are needed to evaluate this possibility. Indeed, significant differences in the rate of successful emergence were observed among tubers collected from plants infested 1 and 2 weeks before harvest which were planted under controlled greenhouse condition (storage study).

Only a small percentage of plants that emerged from ' $\mathrm{Ca}$. L. solanacearum'-infected tubers tested positive for the pathogen. However, under natural circumstances, due to the low vigor and delayed emergence, healthy potato plants would outgrow those infected plants, a conclusion that supports Henne et al. (9). Pitman et al. (18) reported the opposite; in New Zealand, a considerable percentage of $\mathrm{ZC}$-affected tubers emerged and produced ' $\mathrm{Ca}$. L. solanacearum'-positive plants (18). Differences between Pitman's results and those of Henne and this current study possibly can be explained by both biotic and abiotic variations. One major biotic variable is that of pathogen genotype. The two currently identified ' $\mathrm{Ca}$. L. solanacearum' haplotypes are ' $\mathrm{Ca}$. L. solanacearum' A and 'Ca. L. solanacearum' B $(16,32)$, and the less virulent of the two, ' $\mathrm{Ca}$. L. solanacearum' A, is known to be the only haplotype in New Zealand (18). In the current study, 'Ca. L. solanacearum' A and B were present in the infesting psyllid colonies.

Alternatively, or in addition, continuous postharvest plantpathogen interactions might have been a contributing factor affecting emergence of seed potato in the following season. In the current storage study, the percentage of tubers that tested positive for
'Ca. L. solanacearum' increased at all cold-storage sets but one. Subsequently, both pathogen quantity and successful detection increased rapidly when tubers were moved to room temperature. ' $\mathrm{Ca}$. L. solanacearum' titer increased for up to 5 weeks after tubers were removed from cold storage. If tubers were tested after 3 to 4 weeks of placement at room temperature following cold storage, the reliability of ' $\mathrm{Ca}$. L. solanacearum' detection (by quantitative PCR) would be 50 to $>90 \%$. By the fifth week, pathogen quantity is likely to be detectable in most if not all infected tubers because the increasing trend in detecting ' $C a$. L. solanacearum'-positive tubers started to level off within 4 weeks (Fig. 5A and B).

Consistent detection and quantification of ' $\mathrm{Ca}$. L. solanacearum' within plant tissue is needed to determine the pathogen development over time. This can be challenging because of the known heterogeneous spatiotemporal distribution of the pathogen within the potato host $(11,33)$. In the present study to minimize variability, ' $\mathrm{Ca}$. L. solanacearum' titers were monitored within individual potato tubers by removing core samples from close proximity around the stolon attachment point. Although our approach was expected to reduce among-sampling variation, the inflicted tissue damage might have affected tuber respiration and physiology (27). For instance, it has been shown that mechanical wounding pf plant tissue is associated with increases in defense-related polyphenol oxidase activity (2) and jasmonic acid level $(17,19)$. Despite this potential effect, our approach was sensitive enough to detect changes in both the probability of successful ' $\mathrm{Ca}$. L. solanacearum' detection and titer during and following storage.

This study demonstrated that emergence rate of the seed potato infected as late as 1 to 2 weeks prior to harvest can be negatively affected, likely due to the physiological changes triggered in response to ' $\mathrm{Ca}$. L. solanacearum' presence. ' $\mathrm{Ca}$. L. solanacearum' continued to interact with tubers postharvest; however, cold storage appeared to slow down pathogen multiplication. In high-risk areas with high infective-psyllid pressure, harvested potato tubers need to be processed or transferred into cold storage as soon as possible. In such areas, the duration of tuber exposure to relatively warmer
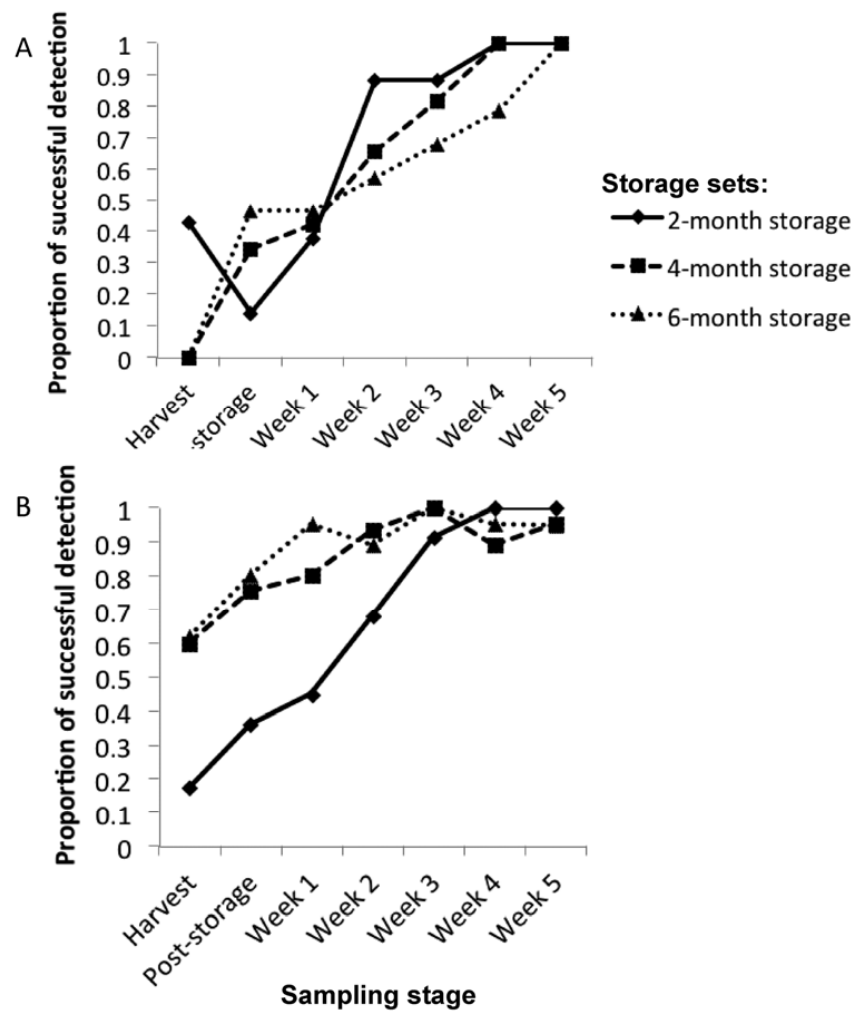

Fig. 5. Successful pathogen detection rate in relation to the highest percentage of tubers that tested positive after cold storage, in tubers infested A, 1 week and B, 2 weeks before harvest. 
temperatures should also be minimized following cold storage to limit ' $C a$. L. solanacearum' multiplication. Continuation of psyllid monitoring until harvest is essential to assess local risk throughout the field season.

Systemic plant pathogens can be translocated throughout host plants and, therefore, can be spread via vegetative production (5). For instance, planting seed potato infected with Potato virus $Y$ (PVY) can contribute to the disease epidemiology, because plants emerging from those PVY-infected tubers could serve as a source of inoculum (6). Although the role of seedborne $\mathrm{ZC}$ in ' $\mathrm{Ca}$. L. solanacearum' epidemiology in North America is negligible, failure to reliably detect the pathogen at harvest in late-season infestations could make disease-free seed certification complicated. Seed potato seed certification is a critical component of national and international trading because ' $\mathrm{Ca}$. L. solanacearum' could be introduced to new geographical locations (23), and dispersed within invaded areas, if the potato psyllid vector is present. We showed that probability of successful pathogen detection increases poststorage over time, a finding that would help in screening tubers from areas with high psyllid pressure late in the season. Pathogen development postharvest and prior to cold storage was not investigated in this study but needs to be addressed in future studies.

\section{Acknowledgments}

We thank J. Gray, J. Arthur, and all of our undergraduate assistants for their help during the course of this study. Funding for this research was provided by United States Department of Agriculture Specialty Crop Research Initiative Zebra Chip award number 2009-51181.

\section{Literature Cited}

1. Buchman, J. L., Sengoda, V. G., and Munyaneza, J. E. 2011. Vector Transmission efficiency of Liberibacter by Bactericera cockerelli (Hemiptera: Triozidae) in zebra chip potato disease: Effects of psyllid life stage and inoculation access period. J. Econ. Entomol. 104:1486-1495.

2. Constabel, C. P., Yip, L., Patton, J. J., and Christopher, M. E. 2000. Polyphenol oxidase from hybrid poplar. Cloning and expression in response to wounding and herbivory. Plant Physiol. 124:285-295.

3. Crosslin, J. M., Olsen, N., and Nolte, P. 2012. First report of zebra chip disease and 'Candidatus Liberibacter solanacearum' on potatoes in Idaho. Plant Dis. 96:453.

4. Dwelle, R. B. 2003. Potato growth and development. Pages 9-11 in: Potato Production Systems. J. G. Stark and S. L. Love, eds. University of Idaho Agricultural Communications, Moscow, ID.

5. Frost, K. E., Groves, R. L., and Charkowski, A. O. 2013. Integrated control of potato pathogens through seed potato certification and provision of clean seed potatoes. Plant Dis. 97:1268-1280.

6. Gray, S., De Boer, S., Whitworth, J., Nolte, P., Singh, R., Boucher, A., and $\mathrm{Xu}$, H. 2010 Potato virus $Y$ : An evolving concern for potato crops in the United States and Canada. Plant Dis. 94:1387-1397.

7. Hamm, P. B., Rondon, S. I., Crosslin, J. M., and Munyaneza, J. E. 2011. A new threat in the Columbia Basin of Oregon and Washington: Zebra chip. Pages 1-5 in: Proc. 11th Annu. SCRI Zebra Chip Rep. Session. F. Workneh, A. Rashed, and C. M. Rush, eds.

8. Hansen, A. K., Trumble, J. T., Stouthamer, R., and Paine, T. D. 2008. A new huanglongbing species, 'Candidatus Liberibacter psyllaurous' found to infect tomato and potato, is vectored by psyllid Bactericera cockerelli (Sulc). Appl. Environ. Microbiol. 74:5862-5865.

9. Henne, D. C., Workneh, F., Wen, A., Price, J. A., Pasche, J. S., Gudmestad, N. C., and Rush, C. M. 2010. Characterization and epidemiological significance of potato plants grown from seed tubers affected by zebra chip disease. Plant Dis. 94:659-665.

10. Kleinkopf, G. E., and Olsen, N. 2003. Storage management. Pages 363-381 in: Potato Production Systems. J. G. Stark and S. L. Love, eds. University of Idaho Agricultural Communications, Moscow, ID.

11. Levy, J., Ravindran, A., Gross, D., Tamborindeguy, C., and Pierson, E. 2011. Translocation of 'Candidatus Liberibacter solanacearum', the zebra chip pathogen, in potato and tomato. Phytopathology 101:1285-1291.

12. Li, W., Abad, J. A., French-Monar, R. D., Rascoe, J., Wen, A., Gudmestad, N. C., Secor, G. A., Lee, I., Duan, Y., and Levy, L. 2009. Multiplex realtime PCR for detection, identification and quantification of 'Candidatus Liberibacter solanacearum' in potato plants with zebra chip. J. Microbiol.
Methods 78:59-65.

13. Li, W., Hartung, J. S., and Levy, L. 2006. Quantitative real-time PCR for detection and identification of 'Candidatus Liberibacter' species associated with citrus huanglongbing. J. Microbiol. Methods 66:104-115.

14. Liefting, L. W., Perez-Egusquiza, Z. C., Clover, G. R. G., and Anderson, J. A. D. 2009. A new 'Candidatus Liberibacter' species in Solanum tuberosum in New Zealand. Plant Dis. 92:1474.

15. McGee, D. C. 1995. Epidemiological approach to disease management through seed technology. Annu. Rev. Phytopathol. 33:445-466.

16. Nelson, W. R., Fisher, T. W., and Munyaneza, J. E. 2011. Haplotypes of 'Candidatus Liberibacter solanacearum' suggest long-standing separation. Eur. J. Plant. Pathol. 130:5-12.

17. Onkokesung, N., Galis, I., von Dahl, C. C., Matsuoka, K., Salus, H. P., Baldwin, I. T. 2010. Jasmonic acid and ethylene modulate local responses to wounding and simulated herbivory in Nicotiana attenuata leaves. Plant Physiol. 153:785-798.

18. Pitman, A. R., Drayton, G. M. Kraberger, S. J., Genet, R. A., and Scott, I. A. W. 2011. Tuber transmission of 'Candidatus Liberibacter solanacearum' and its association with zebra chip on potato in New Zealand. Eur. J. Plant. Pathol. 129:389-398.

19. Rajendran, S., Lin, I. W., Chen, M. J., Chen, C. Y., and Yeh, K. W. 2014 Differential activation of sporamin expression in response to abiotic mechanical wounding and biotic herbivore attach in the sweet potato. BMC Plant Biol. 14:112.

20. Rashed, A., Nash, D., Paetzold, L., Workneh, F., and Rush, C. M. 2012. Transmission efficiency of 'Candidatus Liberibacter solanacearum' and potato zebra chip disease progress in relation to pathogen titer, vector numbers and feeding sites. Phytopathology 102:1072-1085.

21. Rashed, A., Wallis, C. M., Paetzold, L., Workneh, F., and Rush, C. M. 2013. Zebra Chip disease and potato biochemistry: Tuber physiological changes in response to 'Candidatus Liberibacter solanacearum' infection over time. Phytopathology 103:419-442.

22. Rashed, A., Workneh, F., Gray, J., Paetzold, L., and Rush, C. M. 2014. Zebra chip disease development in relation to plant age and time of 'Candidatus Liberibacter solanacearum' infection. Plant Dis. 98:24-31.

23. Ronnie, W. J., Cockerell, V. 2006. Seed-borne disease. Pages 357-372 in: The Epidemiology of Plant Diseases. B. M. Cooke, D. G. Jones, and B. Kaye, eds. Springer, Dordrecht, The Netherlands.

24. Secor, G. A., Rivera, V. V., Abad, J. A., Lee, I. M., Clover, G. R. G., Liefting, L. W., Li, X., and De Boer, S. H. 2009. Association of 'Candidatus Liberibacter solanacearum' with zebra chip disease of potato established by graft and psyllid transmission, electron microscopy, and PCR. Plant Dis. 93:574-583.

25. Shepard, J. F., and Claflin, L. E. 1975. Critical analysis of the principles of seed potato certification. Annu. Rev. Phytopathol. 13:271-293.

26. Stadler, R. H., Blank, I., Varga, N., Robert, F., Hau, J., Guy, P. A., Robert, M. C., and Riediker, S. 2002. Acrylamide from Maillard reaction products Nature 419:449-450.

27. Strehmel, N., Praeger, U., Konig, C., Fehrle, I., Erban, A., Geyer, M., Kopka, J., and van Dongen, J. T. 2010. Time course effects on primary metabolism of potato (Solanum tuberosum) tuber tissue after mechanical impact. Postharvest Biol. Technol. 59:109-116.

28. Swisher, K. D., Munyaneza, J. E., and Crosslin, J. M. 2012. High resolution melting analysis of the cytochrome oxidase I gene identifies three haplotypes of the potato psyllid in the United States. Environ. Entomol. 41:1019-1028.

29. TeKrony, D. M., and Egli, D. B. 1991. Relationship of seed vigor to crop yield: A review. Crop Sci. 31:816-822.

30. Wallis, C. M., Chen, J., and Civerolo, E. L. 2012. Zebra chip-diseased potato tubers are characterized by increased levels of host phenolics, amino acids, and defense-related proteins. Physiol. Mol. Plant Pathol. 78:66-72.

31. Wallis, C. M., Rashed, A., Paetzold, L., Workneh, F., and Rush, C. M. 2013 Similarities and differences in physiological responses to 'Candidatus $\mathrm{Li}$ beribacter solanacearum' infection among different potato cultivars. Phytopathology 104:126-133.

32. Wen, A., Johnson, C., and Gudmestad, N. C. 2012. Comparison and Evaluation of 'Candidatus Liberibacter solanacearum' haplotyping markers. Pages 104-108 in: Proc. 12th Annu. SCRI Zebra Chip Rep. Session. F. Workneh, A. Rashed, and C. M. Rush, eds.

33. Wen, A., Mallik, I., Alvarado, V. Y., Pasche, J. S., Wang, X., Li, W., Levy, L., Lin, H., Scholthof, H. B., Mirkov, T. E., Rush, C. M., and Gudmestad, N. C. 2009. Detection, distribution, and genetic variability of 'Candidatus Liberibacter' species associated with zebra chip complex disease of potato in North America. Plant Dis. 93:1102-1115.

34. Workneh, F., Henne, D. C., Childers, A. C., Paetzold, L., and Rush, C. M. 2012. Assessment of the edge effect in intensity of potato zebra chip disease. Plant Dis. 96:943-947. 